\title{
INDEKS MASSA TUBUH, LINGKAR PINGGANG, DAN RASIO LINGKAR PINGGANG TINGGI BADAN SEBAGAI PREDIKSI HIPERTENSI PADA KARYAWAN
}

\author{
Body Mass Index, Waist Circumference, Rasio Waist Cicumference to Height \\ as Predictor of Hypertenssion among Employee
}

\author{
Atika Fajria, Triyanti, dan Kusharisupeni \\ Departemen Gizi Kesehatan Masyarakat, Fakultas Kesehatan Masyarakat, Universitas Indonesia
}

triyantigizi@gmail.com

ABSTRACT

\begin{abstract}
Accurate blood pressure measurement is using a tool, namely a mercury sphygmomanometer. However, there are limitations such as those carried out by trained personnel and tend to be expensive. This study aims to determine the association of anthropometric measurements in the form of Body Mass Index, waist circumference, and rasio waist circumference to height with blood pressure. The study design was cross sectional with a sample of 89 males and 77 females aged 25 to 60 years old who were taken using a systematic random sampling technique. The results showed that ther was relationship between Body Mass Index, waist circumference, and rasio waist circumference to height with blood pressure. The value of area under the ROC curve $(A U C)$ for three anthropometry indeces range from 0,6 to 0,8. RLPT had the best AUC namely 0,769 for men and 0,0756 for women. The Cut-off point of RLPT in predicting hypertension was 0,57 in men and 0,56 in women. The sensitivity and specificity values of the cut-off points of RLPT measurement were $71,4 \%$ and $70,5 \%$ for men, respectively, and 76,2\% and 57,1\% for women. The rasio waist circumference to height in men and women were the best alternative measures to predict hypertension in adults.
\end{abstract}

Keywords: adult, blood pressure, Body Mass Index, hypertension, rasio waist circumference to height, waist circumference

\begin{abstract}
ABSTRAK
Pengukuran tekanan darah yang akurat dilakukan dengan menggunakan sebuah alat yaitu mercury sphygmomanometer. Namun, terdapat keterbatasan seperti dilakukan oleh tenaga terlatih dan cenderung mahal. Penelitian ini bertujuan untuk mengetahui hubungan pengukuran antropometri berupa indeks masa tubuh (IMT), lingkar pinggang (LP), dan rasio lingkar pinggang tinggi badan (RLPT) terhadap tekanan darah. Disain studi adalah cross sectional dengan sampel 89 laki-laki dan 77 perempuan berumur 25 hingga 60 tahun yang diambil dengan teknik systematic random sampling. Hasil penelitian menunjukkan bahwa terdapat hubungan antara IMT, LP dan RLPT dengan tekanan darah. Nilai area under the ROC curve (AUC) ketiga indeks antropometri antara 0,6 hingga 0,8 . RLPT mempunyai AUC yang paling baik yaitu 0,769 pada laki-laki dan 0,756 pada perempuan. Cut-off point RLPT dalam prediksi hipertensi yaitu 0,57 pada laki laki dan 0,56 pada perempuan. Nilai sensitivitas dan spesifisitas dari cut-off points pengukuran RLPT secara berturut-turut adalah $71.4 \%$ dan $70.5 \%$ pada laki-laki, serta $76.2 \%$ dan $57.1 \%$ pada perempuan. RLPT pada laki-laki dan perempuan merupakan pengukuran alternatif terbaik untuk prediksi hipertensi pada usia dewasa.
\end{abstract}

Kata kunci: dewasa, hipertensi, IMT, lingkar pinggang, RLPT, tekanan darah

\section{PENDAHULUAN}

Hipertensi jarang menimbulkan tanda dan gejala pada fase-fase awal dan banyak orang yang menderita hipertensi namun tidak terdiagnosis (WHO,2019). Penyebab hipertensi yang tidak terdiagnosis ini disebabkan oleh berbagai 
J.Gipas, Mei 2021, Volume 5 Nomor 1 ISSN 2599-0152 eISSN 2599-2465

keterbatasan dalam hal melakukan pemeriksaan yang diantaranya adalah penggunaan mercury sphygmomanometer yang hanya dapat dilakukan oleh tenaga ahli yang terlatih dan harga peralatan yang cenderung mahal. Hal ini menyebabkan pengukuran tekanan darah menjadi sulit dilakukan oleh sebagian besar masyarakat, terutama masyarakat di daerah pedesaan yang memiliki akses terbatas terhadap pelayanan kesehatan. Berdasarkan beberapa keterbatasan dari penggunaan mercury sphygmomanometer ini, munculah berbagai penelitian yang bertujuan untuk mencari alternatif dalam skrining hipertensi, salah satunya menggunakan pengukuran antropometri seperti indeks massa tubuh (IMT), lingkar pinggang (LP), dan rasio lingkar pinggang tinggi badan (RLPT) yang merupakan pengukuran yang digunakan untuk menggambarkan obesitas sentral pada seseorang (Li et al, 2013; Sarry El Din, 2014; Lee et al, 2015; Khaher et al,2019). Obesitas sentral menjadi poin penting karena pada dasarnya distribusi lemak yang terpusat di bagian abdominal pada penderita obesitas sentral menyebabkan peningkatan ukuran lingkar pinggang (LP) dan peningkatan rasio lingkar pinggang tinggi badan (RLPT). Pada penderita obesitas sentral terjadi pertambahan berat badan dan juga peningkatan IMT. http://jos.unsoed.ac.id/index.php/jgps Penderita obesitas sentral memiliki risiko paling tinggi terhadap masalah kesehatan termasuk masalah hipertensi dibandingkan dengan seseorang yang memiliki obesitas perifer. Untuk setiap peningkatan berat badan sebesar $4.5 \mathrm{~kg}$ dapat meningkatkan tekanan darah sebesar $4.5 \mathrm{mmHg}$ (Baker et al,1999)

Metode pengukuran antropometri dipilih sebagai alternatif skrining hipertensi karena dianggap lebih aplikatif untuk diterapkan oleh sebagian besar masyarakat termasuk masyarakat yang tidak memiliki latar belakang pendidikan dari bidang kesehatan. Dan lebih khusus lagi yaitu bagi kader-kader POSBINDU (Pos Pembinaan Terpadu) yang merupakan salah satu pelaksana pelayanan kesehatan yang berperan dalam upaya promotif dan preventif untuk mengendalikan faktor risiko penyakit tidak menular pada masyarakat. Dari sekian banyak jenis pengukuran antropometri, IMT, LP dan RLPT merupakan pengukuran antropometri yang paling banyak digunakan karena memiliki hubungan yang paling baik dengan tekanan darah dan juga memberikan informasi penting mengenai risiko hipertensi serta penyakit kardiovaskular (Sarry El Din et al,2014; Lee et al,2015; Khaher,2019). Selain meneliti apakah ukuran antropometri bisa 
dijadikan sebagai alternatif skrining hipertensi dengan menguji validitasnya, pada beberapa penelitian yang telah dilakukan di berbagai negara juga dilakukan analisis data yang bertujuan untuk menentukan cut-off points dari pengukuran tersebut yang nantinya dapat dijadikan sebagai acuan dalam mendeteksi risiko hipertensi pada usia dewasa.

Sampai saat ini, penelitian mengenai studi tentang pengukuran antropometri dan penentuan cut-off points antropometri terhadap tekanan darah sebagai skrining hipertensi masih sangat jarang dilakukan di Indonesia, terutama pada kelompok usia dewasa. Padahal, mengetahui hipertensi sejak dini merupakan hal yang sangat penting untuk mencegah terjadinya komplikasi masalah kesehatan lainnya (WHO,2013). Karena itu perlu dilakukan penelitian yang betujuan untuk mengetahui indeks antropometri serta cut-off points dari masing-masing indeks yaitu IMT, LP, dan RLPT sebagai prediktor dalam skrining hipertensi pada golongan dewasa.

\section{METODE}

\section{Desain dan tempat}

Desain yang digunakan pada penelitian ini merupakan cross sectional. Penelitian ini dilakukan di kantor Kedeputian Ilmu Pengetahuan Sosial dan http://jos.unsoed.ac.id/index.php/jgps Kemanusiaan Lembaga Ilmu Pengetahuan Indonesia (IPSK LIPI) Jakarta.

\section{Jumlah dan cara pengambilan subjek}

Jumlah sampel dalam penelitian ini adalah 166 orang. Pengambilan sampel dilakukan dengan metode acak sistematik (systematic random sampling) dengan kriteria inklusi adalah usia 25-60 tahun, dan karyawan aktif. Sementara kriteria eksklusi yaitu menderita penyakit infeksi, hamil, atlet, memiliki penyakit jantung dan gagal ginjal. Pengumpulan data dilakukan setelah responden mengisi dan menandatangani inform consent sebagai bentuk pernyataan kesediaan menjadi responden. Data yang dikumpulkan adalah data personal responden seperti nama, jenis kelamin, tempat tanggal lahir, dan usia. Pengukuran darah dilakukan oleh perawat yang telah terampil dengan menggunakan alat mercury sphgymomanomrter dengan tambahan alat berupa stetoskop. Pengukuran tekanan darah akan dilakukan dengan posisi duduk sebanyak 2 kali dengan selang waktu minimal 5 menit dengan menggunakan mercury sphygmometer merek $\mathrm{ABN}$. Sebelum dilakukan pengumpulan data diberitahukan kepada responden agar tidak minum obat hipertensi setelah pukul 9 malam, tidak mengonsumsi kopi, tidak merokok, dan tidak beraktifitas fisik berat 
minimal 30 menit sebelum pengukuran. Pengukuran antropometri seperti berat badan, tinggi badan, lingkar pinggang dilakukan minimal dua kali. Pengukuran berat badan menggunakan timbangan berat badan OMRON tipe HBF 212 dengan ketelitian $0.1 \mathrm{~kg}$, dengan menggunakan pakaian seminimal mungkin. Pengukuran tinggi badan menggunakan microtoise dengan prosedur WHO. Lingkar pinggang menggunakan pita ukur non elastis dengan mengukur titik tengah antara tulang iga paling bawah dengan tulang iliac atas. (WHO,2008). Pengumpul data adalah mahasiswa Prodi gizi Fakultas Kesehatan Masyarakat Universitas Indonesia yang sebelumnya dilakukan persamaan persepsi dan pelatihan. Penelitian ini telah mendapatkan surat lolos kaji etik dari Komisi Etik Riset dan Pengabdian Kesehatan Masyarakat Fakultas Kesehatan Masyarakat Universitas Indonesia.

\section{Analisis Data}

Pengolahan data menggunakan program pengolah data setelah melewati proses pembersihan data. Analisis univariat dilakukan untuk menjelaskan karakteristik dari setiap variabel yang diteliti berupa gambaran mengenai ukuran antropometri seperti IMT, LP, RLPT, http://jos.unsoed.ac.id/index.php/jgps serta gambaran tekanan darah berupa sistolik dan diastolik. Seluruh variabel yang diteliti merupakan data yang bersifat numerik sehingga analisis dilakukan untuk melihat mean, median, nilai maksimum, nilai minimum, standar deviasi dan range. Selain itu, analisis data kategorik juga dilakukan untuk mengetahui jumlah serta prevalensi hipertensi. Dinyatakan hipertensi apabila tekanan darah sistolik lebih besar sama dengan $140 \mathrm{mmHg}$ dan atau tekanan darah diastolik lebih besar sama dengan 90 mmHg (WHO 2019).

Analisis bivariat dilakukan antara masing-masing variabel independen (IMT, LP, RLPT) dengan variabel dependen (tekanan darah). Uji statistik yang digunakan dalam analisis bivariat ini adalah uji korelasi. Analisis dilakukan dengan menggunakan derajat kemaknaan atau $\alpha=0,05$ (CI $95 \%$ ). Analisis atau uji diagnostik dilakukan dengan menggunakan kurva Receiver Operating Characteristic (ROC) untuk melihat kekuatan nilai indeks antropometri (IMT, LP, RLPT) sebagai alat skrining hipertensi. Kurva ROC didapatkan dari hasil tarik ulur antara nilai sensitivitas (pada axis vertikal) dan spesifisitas (pada axis horizontal). Dari hasil analisis ini, selain mendapatkan nilai sensitifitas dan spesifisitas, titik potong kedua nilai 
tersebut akan menentukan besaran cut off point optimal pada alat yang diuji (indikator antropometri) terhadap tekanan darah. Kekuatan hasil uji seluruhnya ditentukan berdasarkan luas Area Under The ROC Curve (AUC). Semakin luas AUC maka semakin baik hasil uji yang dalam hal ini digambarkan dengan nilai 1 pada AUC yang berarti nilai uji sempurna dan sedangkan nilai $<0.5$ menunjukkan hasil uji tidak bermakna.

\section{HASIL DAN PEMBAHASAN}

Dalam penelitian ini menunjukkan jumlah sampel laki-laki sebanyak 53.6\% dan perempuan $46.4 \%$. Rata-rata usia perempuan sedikit lebih tua yaitu 40 tahun, sedangkan rata-rata usia laki-laki yaitu 38 tahun dengan usia minimal 25 tahun dan maksimal 60 tahun. Rata-rata IMT pada laki-laki $\left(26.11 \mathrm{~kg} / \mathrm{m}^{2}\right)$ dan perempuan $\left(26.62 \mathrm{~kg} / \mathrm{m}^{2}\right)$ menunjukkan nilai yang tidak jauh berbeda. Gambaran status gizi menurut IMT, berdasarkan klasifikasi WHO-Asia Pasifik (WHO,2000) diketahui bahwa sebagian besar responden (40\%) memiliki status gizi obesitas, gemuk sebesar 18\%, dan kurus $4 \%$ serta $38 \%$ normal.

Angka hipertensi pada penelitian ini sebesar 29,5\%. Hasil penelitian ini sedikit lebih tinggi jika dibandingkan dengan angka nasional tahun 2013 http://jos.unsoed.ac.id/index.php/jgps $(25,8 \%)$, namun lebih rendah jika dibandingkan dengan angka nasional tahun 2018 (34,8\%) (Kemenkes RI,2018). Hal ini menunjukkan bahwa masalah hipertensi pada lingkungan kerja IPSK LIPI sudah menjadi bagian dari masalah kesehatan masyarakat yang perlu untuk ditanggulangi dan diantisipasi. Berdasarkan jenis kelamin, kasus hipertensi lebih banyak pada laki laki $(16,8 \%)$ dibandingkan perempuan $(12,6 \%)$. Angka hipertensi pada penelitian ini tidak berbeda jauh dengan hasil di India yang mendapatkan 31,7\% laki laki menderita hipertensi dan $11,3 \%$ perempuan menderita hipertensi (Dua et al,2014), penelitian di Yordania mendapatkan $27,1 \%$ laki laki hipertensi dan $18,5 \%$ perempuan hipertensi (Khaher,2019). Sementara hasil penelitian di Taiwan mendapatkan angka hipertensi yang jauh lebih rendah yaitu 6,2\% untuk laki laki dan 3,8\% untuk perempuan ( $\mathrm{Li}$ et al,2013). Perbedaan ini kemungkinan disebabkan perbedaan sampel dimana penelitian di India dan Yordania sampel berasal dari masyarakat, sementara penelitian di Taiwan menggunakan sampel dari pengunjung yang melakukan cek kesehatan dari salah satu rumah sakit. Pada umumnya orang yang datang ke rumah sakit untuk pemeriksaan kesehatan mempunyai 
kesadaran yang tinggi terhadap kesehatan termasuk hipertensi sehingga mempunyai gaya hidup yang baik untuk mencegah penyakit termasuk hipertensi.

Tekanan darah sistolik dan diastolik laki laki $(122 / 79 \mathrm{mmHg})$ lebih tinggi dibandingkan perempuan (117/75 $\mathrm{mmHg}$ ). Hasil penelitian ini sejalan dengan hasil penelitian sebelumnya yang dilakukan di Taiwan (Li et al 2013), India (Dua et al, 2014) dan Korea (Lee et al, 2015). Tekanan darah yang lebih tinggi pada laki-laki dibandingkan perempuan disebabkan oleh hormon sex. Salah satu hormon yang berpengaruh terhadap tekanan darah yaitu hormon androgen pada laki-laki dan hormon esterogen pada perempuan. Hormon androgen berkontribusi terhadap terjadinya vasokonstriksi pada pembuluh darah, sedangkan hormon esterogen diketahui bersifat protektif terhadap peningkatan tekanan darah. Disamping itu, pada lakilaki simpanan lemak lebih banyak terakumulasi pada bagian atas atau abdominal, sedangkan pada perempuan simpanan lemak lebih banyak terakumulasi pada tubuh bagian bawah. Berdasarkan penelitian ditemukan bahwa penyakit kardiovaskuler dan komplikasi metabolik akibat obesitas lebih sering terjadi pada pasien dengan fenotipe obesitas tubuh bagian atas, yang disebut http://jos.unsoed.ac.id/index.php/jgps sebagai tipe tubuh "android", dibandingkan dengan obesitas tubuh bagian bawah, yang disebut sebagai tipe tubuh "gynoid." (Tchernof and Depres,2013); (Dua et al,2014). Hasil penelitian di Korea menunjukkan bahwa hipertensi cenderung lebih tinggi pada laki-laki dibandingkan perempuan, namun setelah usia 60 tahun hipertensi cenderung meningkat dan lebih besar dibanding lakilaki (Choi et al, 2017). Hal ini terkait rendahnya hormon estrogen sebagai protektif hipertensi yang mulai menurun setelah perempuan mengalami menopause. (Tchernof and Depres,2013) Hasil uji korelasi pada penelitian ini dibedakan berdasarkan jenis kelamin. Tabel 2 menunjukkan hasil korelasi antara ketiga indeks antropometri (IMT,LP,RLPT) dengan tekanan darah sistolik maupun diastolik baik pada laki laki dan perempuan mempunyai korelasi yang bermakna $(\mathrm{p}<0,01)$ dengan kekuatan korelasi sedang. Hasil penelitian ini didukung oleh penelitian sebelumnya di Taiwan (Li et al, 2013). Sementara studi di Mesir mendapatkan korelasi yang bermakna antara IMT dan LP dengan tekanan darah sistolik dan diastolik baik laki laki maupun perempuan dengan kekuatan sedang. Terdapat korelasi bermakna antara RLPT dengan tekanan darah sistolik dan diastolik pada laki laki 
dengan kekuatan rendah, namun pada perempuan terdapat korelasi dengan sistolik dengan kekuatan rendah namun tidak untuk diastolik yang tidak berkorelasi (Sarry El Din et al, 2014).

Pengukuran lingkar pinggang juga dimaksudkan untuk menggambarkan obesitas sentral pada seseorang. Hanya saja, faktor tinggi badan tidak diperhitungkan dalam pengukuran ini sehingga mungkin saja hasil yang didapatkan tidak sepenuhnya benar-benar dapat menggambarkan obesitas sentral pada orang dengan ketinggian tertentu (Ashwell and Browning,2011). Meskipun tidak memiliki hubungan yang sangat kuat, namun lingkar pinggang pada umumnya dapat dijadikan alternatif skrining tekanan darah.

Nilai AUC dapat digunakan untuk menilai kekuatan prediksi risiko tersebut. Pada penelitian ini, ketiga indeks antropometri memiliki nilai AUC antara 0,6 sampai 0,8 yang menggambarkan kekuatan uji yang sedang. Namun jika dibandingkan diantara ketiga indeks antropometri tersebut maka RLPT menunjukkan performa uji yang paling baik, yaitu (0.769) pada laki-laki dan (0.756) pada perempuan.

Hasil penelitian ini mendukung penelitian sebelumnya di Taiwan (Li et al, 2013), di Korea (Lee et al, 2015) dan di http://jos.unsoed.ac.id/index.php/jgps

Yordania (Khaher 2019) yang mendapatkan juga bahwa RLPT dapat memprediksi hipertensi lebih baik dibanding IMT, dan LP. Hasil penelitian di Taiwan mendapatkan AUC RLPT pada laki laki sebesar 0,735 maupun perempuan 0,835 (Li etal, 2013), penelitian di Yordania yang mendapatkan pada laki laki 0,72 dan perempuan 0,66 (Khader et al, 2019), sementara penelitian di Korea 0,62 untuk laki-laki dan 0,68 untuk perempuan (Lee et al, 2015). Namun hasil yang berbeda diperoleh pada studi di Mesir yang mendapatkan justru LP merupakan indeks antropometri yang lebih baik untuk memprediksi hipertensi baik pada laki laki maupun perempuan dibanding IMT dan RLPT (Sarry El Din, 2014). Hasil studi meta analisis menunjukkan bahwa RLPT merupakan indeks antropometri yang lebih baik dibandingkan IMT dalam memprediksi risiko kardiovaskuler termasuk hipertensi (Savva et al, 2013).

RLPT memberikan gambaran mengenai perbandingan antara lingkar pinggang dan tinggi badan. RLPT memberikan gambaran lemak abdominal yang lebih akurat dimana keberadaan lemak abdominal sangat erat kaitannya dengan peningkatan tekanan darah. Komposisi lemak berlebih yang banyak terjadi pada bagian abdominal 
menyebabkan meningkatnya kebutuhan insulin guna membantu aktifitas lipolisis lemak. Pada batasan tertentu, hal ini dapat meningkatkan resiko terjadinya resistensi insulin. Resistensi insulin dapat mengakibatkan produksi insulin yang tidak terkendali, hal ini menyebabkan meningkatnya reabsorbsi natrium dan terganggunya natriuresis di ginjal. Dampaknya, volume sekuncup jantung serta curah jantung akan meningkat dan pada akhirnya akan menyebabkan peningkatan tekanan darah (Depres and Tchernof,2013); (Jiang et al,2016). Selain menilai obesitas sentral, RLPT juga turut memperhitungkan tinggi badan sebagai salah satu faktor yang menggambarkan obesitas sentral. RLPT lebih sensitif daripada lingkar pinggang di beberapa populasi berbeda karena dapat menyesuaikan terhadap tinggi badan yang berbeda (Ashwell \& Hsieh, 2005). Oleh sebab itu, RLPT memiliki korelasi paling baik jika dibandingkan pengukuran lainnya.

$\begin{array}{ccc}\text { RLPT } & \text { tidak } & \text { hanya } \\ \text { menggambarkan } & \text { obesitas } & \text { namun }\end{array}$
berhubungan bermakna dengan sindrom metabolik yang dapat memprediksi kesakitan dan kematian. Pengukuran RLPT yang lebih praktis, mudah dan murah dibandingkan IMT karena mengukur tinggi badan yang lebih stabil, http://jos.unsoed.ac.id/index.php/jgps mengukur LP sebagai pengganti berat badan yang memelukan peralatan pengukuran berat badan yang relatif lebih mahal. RLPT menggunakan cut-off point 0,5 yang dapat digunakan oleh laki-laki dan perempuan, di semua etnik, semua polulasi, dan semua kelompok umur. Hal ini berbeda dengan IMT yang mempunyai cut-off point yang berbeda berdasarkan etnik dan populasi serta LP yang berbeda antar jenis kelamin. Hasil penelitian ini mendukung pesan kesehatan masyarakat "keep your waist circumference to less than half your height" untuk mencegah risiko kardiometabolik, tidak hanya hipertensi namun juga diabetes melitus. (Ashwell and Browning,2011).

Cut-off points optimal RLPT dari penelitian ini dalam mendeteksi hipertensi pada laki-laki dan perempuan mendekati sama, yaitu 0.57 pada laki-laki dan 0.56 pada perempuan. Sejalan dengan penelitian ini, Ashwell \& Hseih (2005) telah merekomendasikan cut-off points yang sama pada laki-laki dan perempuan yaitu 0.5. Selain itu, hasil yang tidak jauh berbeda juga ditunjukkan pada penelitian yang dilakukan di Korea dengan cut-off points optimal untuk mendeteksi hipertensi yaitu 0.49 pada laki-laki dan 0.51 pada perempuan (Lee et al, 2015). Sementara studi di Taiwan menunjukkan 
J.Gipas, Mei 2021, Volume 5 Nomor 1 ISSN 2599-0152 eISSN 2599-2465

cut-off points 0,509 untuk laki laki dan 0,485 untuk perempuan ( $\mathrm{Li}$ et al, 2013).

Cut-off points yang mendekati sama antara laki-laki dan perempuan ini dikarenakan rata-rata pada laki-laki memiliki tinggi badan yang lebih tinggi disertai dengan lingkar pinggang yang juga lebih besar dibandingkan perempuan. Begitupun pada wanita, rata-rata memiliki tinggi badan yang lebih pendek disertai dengan lingkar pinggang yang lebih kecil dari laki-laki. Berbedanya nilai cut-off points pengukuran antropometri untuk prediksi hipertensi di beberapa penelitian dipengaruhi oleh banyak faktor salah satunya adalah perbedaan dalam sumber sampel dan umur sampel yang digunakan.

Pada penelitian ini mendapatkan cut-off points IMT untuk memprediksi hipertensi tidak jauh berbeda antara lakilaki $(26,2 \mathrm{~kg} / \mathrm{m} 2)$ dan perempuan $(26,3$ $\mathrm{kg} / \mathrm{m} 2$ ). Jika dibandingkan dengan klasifikasi IMT menurut WHO Asia Pasifik, hasil cut-off points ini berada pada kriteria obesitas tingkat I (25.0 - 29.9 $\mathrm{kg} / \mathrm{m}^{2}$ ). Hal ini menunjukkan bahwa IMT bisa digunakan dalam mendeteksi hipertensi yang disebabkan obesitas pada dewasa. Studi di Mesir dan Yordania mendapatkan cut-off point yang lebih besar dari penelitian ini. Studi di Mesir memperoleh cut-off points IMT untuk memprediksi hipertensi adalah 27,98 http://jos.unsoed.ac.id/index.php/jgps $\mathrm{kg} / \mathrm{m} 2$ untuk laki laki dan 30,08 kg/m2 untuk perempuan. Studi di Yordania memperlihatkan cut-of points IMT untuk laki-laki adalah $27 \mathrm{~kg} / \mathrm{m} 2$ dan perempuan sebesar $30 \mathrm{~kg} / \mathrm{m} 2$. Sementara studi di Taiwan mendapatkan cut-off points yang lebih rendah dengan penelitian ini. Studi di Taiwan menunjukkan cut-off points IMT untuk laki-laki sebesar 25,74 kg/m2 dan perempuan sebesar 23,46 kg/m2. (Li et al,2013); (Sarry El Din,2014); (Khaher,2019).

Cut-off points LP untuk deteksi hipertensi pada penelitian ini mendapatkan 92,3 cm untuk laik-laki dan $86,6 \mathrm{~cm}$ untuk perempuan. Hasil ini lebih tinggi sedikit dibandingkan dengan rekomendasi WHO yang merekomendasikan cut-off points $90 \mathrm{~cm}$ untuk laki-laki dan $80 \mathrm{~cm}$ untuk perempuan (WHO,2008). Berbeda dengan hasil penelitian ini, hasil studi di Taiwan mendapatkan cut-off points LP yang lebih kecil baik laki-laki $(87,9 \mathrm{~cm})$ maupun perempuan $(76,4 \mathrm{~cm})$. Studi di Yordania dan Mesir mendapatkan cut-off points LP untuk prediksi hipertensi lebih besar pada kedua jenis kelamin. Studi di Yordania menunjukkan cut-off points LP sebesar $95,75 \mathrm{~cm}$ untuk laki laki dan $87,75 \mathrm{~cm}$ untuk perempuan. Studi di Mesir menunjukkan cut-off points LP laki-laki sebesar $100 \mathrm{~cm}$ untuk laki-laki dan $90 \mathrm{~cm}$ 
untuk perempuan ( $\mathrm{Li}$ et al 2013); (Khaher 2019); (Sarry El Din 2014). Lingkar pinggang merupakan ukuran yang digunakan untuk melihat lemak yang terakumulasi pada bagian abdominal. Pengukuran lingkar pinggang merupakan pengukuran yang paling mudah dan murah dibandingkan pengukuran lainnya karena hanya memerlukan pita meter untuk melakukan pengukurannya. Akan tetapi cut-off points lingkar pinggang akan berbeda pada jenis kelamin dan juga pada etnis yang berbeda (WHO,2008).

Untuk cut-off points RLPT, pada penelitian ini mendapatkan 0,57 untuk laki-laki dan 0,56 untuk perempuan. Hasil yang sama didapatkan oleh penelitian di Mesir. Sementara hasil yang tidak jauh berbeda didapatkan dari studi di Yordania dan Taiwan. Studi di Taiwan mendapatkan cut-off points RLPT sebesar 0,509 untuk laki-laki dan 0,485 untuk perempuan. Studi di Yordania menunjukkan cut-off points RLPT untuk laki-laki yaitu 0,57 untuk laki-laki dan http://jos.unsoed.ac.id/index.php/jgps 0,60 untuk perempuan ( $\mathrm{Li}$ et al,2013); (Sarry El Din,2014); (Khaher,2019) Berbedanya nilai cut-of points untuk pengukuran antropometri dipengaruhi oleh banyak faktor salah satunya adalah perbedaan dalam menentukan sampel, jumlah sampel, komposisi laki-laki dan perempuan dan umur sampel yang digunakan.

Nilai sensitivitas dan spesifisitas dari cut-off points dari pengukuran RLPT yang dihasilkan pada penelitian ini secara berturut-turut adalah $71.4 \%$ dan $70.5 \%$ pada laki-laki, serta $76.2 \%$ dan $57.1 \%$ pada perempuan. Hasil ini tidak berbeda jauh jika dibandingkan dengan penelitian Lee et al (2015) dengan nilai sensitivitas dan spesifisitas berturut-turut yaitu $69.27 \%$ dan $48.91 \%$ pada laki-laki, serta $75.13 \%$ dan $53.18 \%$ pada perempuan. Nilai sensitivitas berdasarkan penelitian ini memiliki hasil yang cukup baik, dan memiliki arti bahwa RLPT cukup baik digunakan untuk mendeteksi terjadinya kasus hipertensi (Hastono, 2011).

Tabel 1. Hasil Pengukuran Tekanan Darah dan Antropomentri Karyawan

\begin{tabular}{lccc}
\hline \multicolumn{1}{c}{ Variabel } & Mean & SD & Nilai Min-Max \\
\hline Tekanan Darah Sistolik (mmHg) & & & \\
Laki-Laki & 122 & 14.88 & $90-160$ \\
Perempuan & 117 & 20.99 & $90-160$ \\
Total & 120 & 18.07 & $90-160$ \\
\hline Tekanan Darah Diastolik (mmHg) & & & \\
Laki-Laki & 79 & 10.07 & $60-100$ \\
Perempuan & 75 & 15.04 & $50-150$ \\
Total & 77 & 11.59 & $50-100$ \\
\hline
\end{tabular}


J.Gipas, Mei 2021, Volume 5 Nomor 1

ISSN 2599-0152 eISSN 2599-2465

http://jos.unsoed.ac.id/index.php/jgps

\begin{tabular}{lccc}
\hline IMT $\left(\mathrm{kg} / \mathrm{m}^{2}\right)$ & & & \\
Laki-Laki & 26.11 & 50.74 & $16.99-43.69$ \\
Perempuan & 26.62 & 48.60 & $17.18-42.07$ \\
Total & 26.70 & 4.97 & $16.99-43.69$ \\
\hline Lingkar Pinggang $(\mathrm{cm})$ & & & \\
Laki-Laki & 89.96 & 12.96 & $66.1-128.0$ \\
Perempuan & 85.41 & 11.23 & $61.0-120.5$ \\
Total & 87.85 & 12.36 & $61.0-128.0$ \\
\hline RLPT & & & \\
Laki-Laki & 0.54 & 0.08 & $0.40-0.77$ \\
Perempuan & 0.56 & 0.77 & $0.38-0.78$ \\
Total & 0.55 & 0.78 & $0.38-0.78$ \\
\hline
\end{tabular}

Tabel 2. Analisis Korelasi Pengukuran Antropometri dengan Tekanan Darah Pada Karyawan

\begin{tabular}{lcccc}
\hline \multirow{2}{*}{ Variabel } & \multicolumn{2}{c}{ Sistolik } & \multicolumn{2}{c}{ Diastolik } \\
\cline { 2 - 5 } & Koefisien Korelasi (r) & $p$ value & Koefisien Korelasi (r) & $p$ value \\
\hline Laki-laki & & & & \\
RLPT & 0,378 & 0.000 & 0.452 & 0.000 \\
Lingkar Pinggang & 0,324 & 0,002 & 0.401 & 0.000 \\
IMT & 0.322 & 0,002 & 0.354 & 0.001 \\
Perempuan & & & & \\
RLPT & 0.457 & 0.000 & 0.334 & 0.003 \\
Lingkar Pinggang & 0.467 & 0.000 & 0.335 & 0.003 \\
IMT & 0.423 & 0.000 & 0.294 & 0.010 \\
\hline
\end{tabular}

Tabel 3 Nilai AUC Pengukuran Antropometri Pada Karyawan

\begin{tabular}{lccc}
\hline \multicolumn{1}{c}{ Variabel } & RLPT & Lingkar Pinggang & IMT \\
\hline Laki-Laki & $0.769(0.665-0.874)$ & $0.73(0.619-0.841)$ & $0.723(0.613-0.833)$ \\
Perempuan & $0.756(0.632-0.880)$ & $0.743(0.617-0.869)$ & $0.659(0.519-0.797)$ \\
\hline
\end{tabular}

Tabel 4 Cut-off Point Pengukuran Antropometri Untuk Prediksi Hipertensi Pada Karyawan

\begin{tabular}{|c|c|c|c|c|c|c|c|c|c|}
\hline \multirow[t]{2}{*}{ Pengukuran } & \multicolumn{3}{|c|}{ RLPT } & \multicolumn{3}{|c|}{ Lingkar Pinggang } & \multicolumn{3}{|c|}{ IMT } \\
\hline & Cutoff & Sensitivitas & Spesifitas & Cutoff & Sensitivitas & Spesifitas & Cutoff & Sensitivitas & Spesifitas \\
\hline Laki-laki & 0.57 & 0.714 & 0.705 & 92.3 & 0.714 & 0.656 & 26.2 & 0.679 & 0.607 \\
\hline Perempuan & 0.56 & 0.762 & 0.661 & 86.6 & 0.762 & 0.661 & 26.3 & 0.667 & 0.625 \\
\hline
\end{tabular}




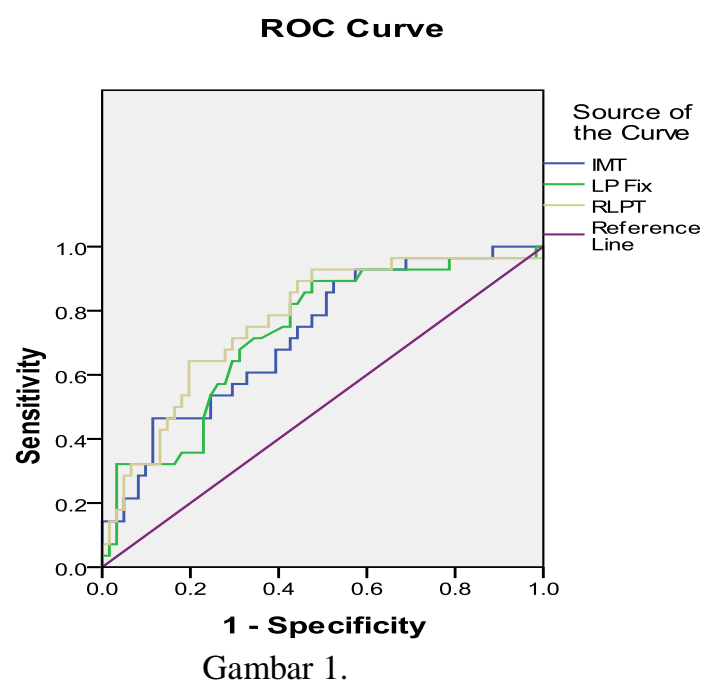

Kurva ROC pengukuran antropometri pada laki-laki

\section{KESIMPULAN}

Terdapat hubungan antara pengukuran IMT, lingkar pinggang dan RLPT dengan tekanan darah pada kedua jenis kelamin. RLPT merupakan pengukuran antropometri yang memiliki hubungan yang sedang dengan nilai koefisien korelasi yang paling baik dibandingkan kedua pengukuran lainnya pada kedua jenis kelamin. Cut-off points RLPT yang memiliki validitas paling optimal diantara ketiga pengukuran dalam mendeteksi kasus hipertensi yaitu 0.57 pada laki-laki dan 0.56 pada perempuan. Pada situasi dan kondisi dimana pengukuran tekanan darah tidak dapat dilakukan, baik karena tidak ada tenaga ahli atau karena ketidaktersediaan alat, pengukuran antopometri terutama RLPT

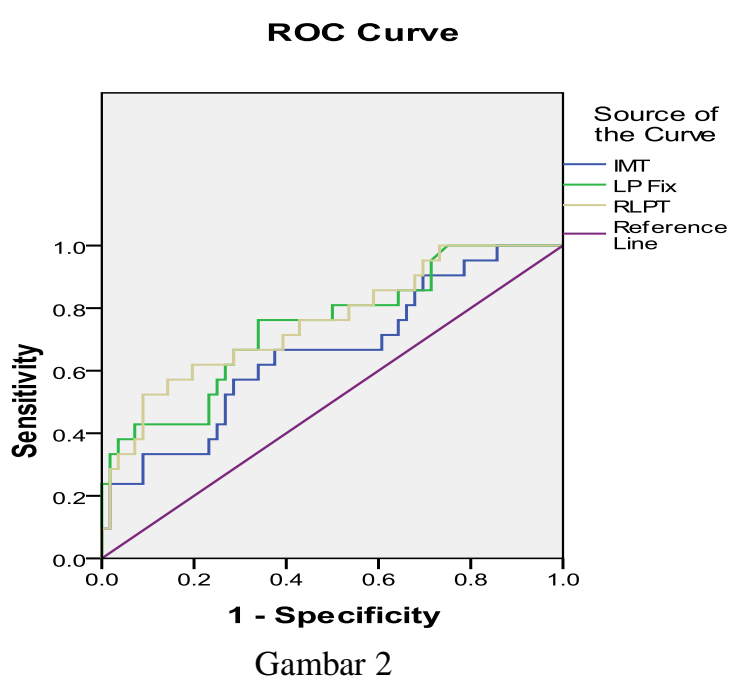

Kurva ROC pengukuran antropometri pada perempuan kasus hipertensi.

\section{DAFTAR PUSTAKA}

Ashwell, M., \& Browning, L. M. 2011. The increasing importance of waist-to-height ratio to assess cardiometabolic risk: A plea for consistent terminology. Open Obesity Journal, 3(May 2011), 70-77. https://doi.org/10.2174/1876823701103 $\underline{010070}$

Ashwell, M., \& Hsieh, S. D. 2005. Six reasons why the waist-to-height ratio is a rapid and effective global indicator for health risks of obesity and how its use could simplify the international public health message on obesity. International Journal of Food Sciences and Nutrition, 56(5),

303-307. https://doi.org/10.1080/0963748050019 $\underline{5066}$

Baker,J.L.,Oisen,L.W.,Sorensen,T.I.A.1999. Childhood Body-Mass Index and the Risk of Coronary Heart Disease in Adulthood. New England journal. 
318(7197),

1565.

https://doi.org/10.1136/bmj.318.7197.1

$565 \mathrm{a}$

Choi, H. M., Kim, H. C., \& Kang, D. R. 2017. Sex differences in hypertension prevalence and control: Analysis of the 2010-2014 Korea national health and nutrition examination survey. PLoS ONE, 12(5), 1-12. https://doi.org/10.1371/journal.pone.01 78334

Dua, S., Bhuker, M., Sharma, P., Dhall, M., \& Kapoor, S. 2014. Body mass index relates to blood pressure among adults. North American Journal of Medical Sciences, 6(2), 89-95. https://doi.org/10.4103/19472714.127751

Hastono, Priyo Susanto.2011. Analisis Data Kesehatan. Depok: Universitas Indonesia.

Jiang, S. Z., Lu, W., Zong, X. F., Ruan, H. Y., \& Liu, Y. 2016. Obesity and hypertension. Experimental and Therapeutic Medicine, 12(4), 23952399.

https://doi.org/10.3892/etm.2016.3667

Kementrian Kesehatan Republik Indonesia. 2019. Riset Kesehatan Dasar. Jakarta: Badan Penelitian dan Pengembangan Kesehatan Kementrian Kesehatan RI.

Khader, Y., Batieha, A., Jaddou, H., ElKhateeb, M., \& Ajlouni, K. 2019. The performance of anthropometric measures to predict diabetes mellitus and hypertension among adults in Jordan. BMC Public Health, 19(1), 1-9. https://doi.org/10.1186/s12889-0197801-2

Lee, J. W., Lim, N. K., Baek, T. H., Park, S. H., \& Park, H. Y. 2015. Anthropometric indices as predictors of hypertension among men and women aged 40-69 years in the Korean population: The Korean Genome and Epidemiology Study. BMC Public Health, 15(1), 1-7.
J.Gipas, Mei 2021, Volume 5 Nomor 1

ISSN 2599-0152 eISSN 2599-2465

http://jos.unsoed.ac.id/index.php/jgps

https://doi.org/10.1186/s12889-015-

$1471-5$

Li, W. C., Chen, I. C., Chang, Y. C., Loke, S. S., Wang, S. H., \& Hsiao, K. Y. 2013. Waist-to-height ratio, waist circumference, and body mass index as indices of cardiometabolic risk among 36,642 Taiwanese adults. European Journal of Nutrition, 52(1), 57-65. https://doi.org/10.1007/s00394-0110286-0

Sarry El Din, A. M., Zaki, M. E., Kandeel, W. A., Mohamed, S. K., \& El-Wakeel, K. H. 2014. Cut-off values of anthropometric indices for the prediction of hypertension in a sample of Egyptian adults. Open Access Macedonian Journal of Medical Sciences, 2(1), 8994.

https://doi.org/10.3889/oamjms.2014.01 $\underline{6}$

Savva, S. C., Lamnisos, D., \& Kafatos, A. G.2013. Predicting cardiometabolic risk: Waist-to-height ratio or BMI. A metaanalysis. Diabetes, Metabolic Syndrome and Obesity: Targets and Therapy, 6, 403-419.

https://doi.org/10.2147/DMSO.S34220

Tchernof, A., \& Després, J. P. 2013. Pathophysiology of human visceral obesity: An update. Physiological Reviews, 93(1), 359-404. https://doi.org/10.1152/physrev.00033.2 011

World Health Organization. 2000. Redefining obesity and its treatment. In Geneva, Switzerland:WorldHealthOrganization. https://apps.who.int/iris/bitstream/handl e/10665/206936/0957708211_eng.pdf. [diakses tanggal 30 November 2020]

World Health Organisation.2008. WHO | Waist Circumference and Waist-Hip Ratio. Report of a WHO Expert Consultation. Geneva, 8-11 December 2008. December, 8-11. http://www.who.int 
World Health Organization.2013. Global

Brief on Hypertension: Silent Killer,

Global Public Health Crisis. https://www.who.int/cardiovascular_dis eases/publications/global brief hyperte nsion/en/ [diakses tanggal 30 November 2020]

World Health Organization. 2019. Hypertension..

https://www.who.int/news-room/factsheets/detail/hypertension [diakses tanggal 21 November 2020] 